Pawet Sut

\title{
Nienadążanie prawa za rozwojem społecznym a cele prawa
}

1. Antycypując dalsze rozważania zawarte w niniejszym opracowaniu, należy stwierdzić, iż zagadnienie „nienadążania prawa za rozwojem społecznym” nie może być utożsamiane jedynie z problematyką luk w prawie, w tym w szczególności luk aksjologicznych ${ }^{1}$. Podczas gdy - sporny, jak wiadomo, w prawoznawstwie - problem luk dotyczy kompletności (niekompletności) systemu prawa, to owo nienadążanie transponuje problem kompletności (niekompletności) systemu do społecznych potrzeb, wartości i celów. Upraszczając więc - problem luk ma charakter teoretyczno-techniczny, a być może filozoficzny (w odniesieniu do luk aksjologicznych), zaś anonsowany problem nienadążania prawa ma przede wszystkim wymiar społeczny. Wypada tu zaznaczyć, że realnie obowiązujące prawo (w danym czasie i na danym terytorium) nie reguluje oczywiście jakiegoś abstrakcyjnego czy nawet „konkretnego” procesu rozwoju społecznego, czy szerzej - zmian społecznych, lecz ewentualnie reguluje ${ }^{2}$ jakieś stany faktyczne, do których odnosi się jakaś podlegająca rozwojowi cecha systemu społecznego (np. postęp technologiczny)

Po części zaczerpnięty z języka potocznego tytuł niniejszego tekstu ma charakter metaforyczny. Po pierwsze, wyraża on założenie istnienia możliwej relacji (,nienadążania”) pomiędzy ontologicznie złożonym przecież zjawiskiem zwanym ,prawem” i wielowątkowym, występującym na różnych poziomach społecznych, procesem zwanym nie tylko w socjologii „rozwojem społecznym”".

1 Na temat luk w prawie por. np. L. Morawski, Zasady wyktadni prawa, Toruń 2006, s. 131-133.

2 Dla uproszczenia w odniesieniu do roli spełnianej przez tę regulację używać będę określeń takich jak: „realizacja” lub „ochrona” (albo ich brak) społecznych potrzeb, wartości i celów albo wartości-celów.

3 Dla porządku należy dodać, że zawarte w pracy rozważania nie dotyczą tych wszystkich sytuacji, gdy prawo „wyprzedza” społeczne potrzeby lub „wymusza” (inicjuje) zmiany stosunków społecznych.

4 Rozwój społeczny w ramach wizji systemowej społeczeństwa definiuje się jako proces (rozwijania się potencjału zawartego w istocie systemu społecznego): (1) kierunkowy, co oznacza, że żaden ze stanów systemu nie powtarza się na innym etapie; (2) każdy późniejszy stan systemu przedstawia wyższy poziom wybranej cechy lub zbliża go do pewnego stanu pożądanego; (3) proces ten stymulują immanentne (wewnętrzne, endogenne, autodynamiczne) skłonności systemu 
Po drugie, uwzględniając dominującą w naszej kulturze liniową koncepcję cza$\mathrm{su}^{5}$ oraz czasową lokalizację (sekwencję) zdarzeń lub zjawisk względem siebie (wcześniej, później, równocześnie) ${ }^{6}$, pojęcie nienadążania wskazywałoby (zapewne słusznie), że prawo podąża za jakimiś problemami - jest reakcją na potrzebę społeczną (a więc najpierw powstaje problem, a następnie jego - taka czy inna - regulacja). W istocie rzeczy przedmiotem niniejszych rozważań będzie też dalsza (kolejna) sekwencja, tzn. sytuacja (I) gdy akt prawotwórczy istnieje i jednocześnie spełnione są warunki realności podstawy aksjologicznej tego aktu prawotwórczego (o czym szerzej w pkt 6 niniejszego opracowania), ale z jakichś przyczyn związanych ze społecznym rozwojem regulacja ta przestaje być aktualna, a nie tylko sytuacja (II) „pierwotnego” braku regulacji społecznej potrzeby, wartości, celu?

2. Termin „nienadążanie” (lub „nadążanie”) odnoszony do prawa, i przy tym określający relację tego prawa do regulowanej przez nie materii, ma więc charakter potoczny, zaś z perspektywy teoretycznej - stwierdzenie (teza), że „prawo nie nadąża za rozwojem społecznym” (zjawisko zwane dalej „nienadążaniem prawa” lub „NP”), lub że prawo nie nadąża za jakimiś nowymi problemami generowanymi przez ten rozwój, jest - prima facie - trywialne. Z drugiej strony, społeczny rozwój generuje (często trudne do przewidzenia, a w każdym razie wciąż „nowe”) problemy mające wpływ na życie jednostek i zbiorowości. Skoro więc poszczególne sfery życia społecznego podlegają temu procesowi, to wydaje się, że problemem co najmniej praktycznym jest kwestia „przystawania” (dopasowania, dostosowania) regulacji prawnej (która też przecież podlega ciągłym przekształceniom) do podlegającej tej regulacji materii ${ }^{8}$.

(P. Sztompka, Socjologia zmian społecznych, Kraków 2005, s. 23). Natomiast zgodnie z - opozycyjnym do modelu systemowego - modelem dynamicznego pola społecznego (w ramach którego społeczeństwo jest postrzegane nie jako sztywny system, lecz jako dynamiczne pole relacji między ludźmi, które rozszerza się, kurczy, wzmacnia, osłabia, scala, rozpada itd.), rozwój społeczny definiuje się jako różnicowanie, ekspansję, krystalizację, formowanie się pola społecznego w różnych wymiarach, wynikające z wewnętrznych właściwości (P. Sztompka, Socjologia zmian..., s. 24-27).

5 P. Sztompka, Socjologia. Analiza społeczeństwa, Kraków 2002, s. 483.

${ }^{6}$ Ibidem, s. 475-476.

7 Po trzecie, tytuł niniejszego opracowania mówi o „celach prawa”, podczas gdy jedynie dla porządku należy przypomnieć, że cele może tylko wyznaczać i realizować człowiek (por. M. Wojciechowski, Celowość prawa, [w:] J. Zajadło (red.), Leksykon współczesnej teorii i filozofii prawa. 100 podstawowych pojęć, Warszawa 2007, s. 30).

8 Przykładowo, w podsumowaniu uzasadnienia wyroku z dnia 14 grudnia 2011 r. (SK 42/09, OTK-A 2011/10/118) TK stwierdził m.in. (niestety, bez bliższego wyjaśnienia): „Wyrok niniejszy [stwierdzający niekonstytucyjność sankcji karnej za wydawanie czasopisma bez rejestracji, w zakresie dotyczącym czasopism drukowanych - dop. P. S.] sygnalizuje ustawodawcy, że ustawa Prawo prasowe, obowiązująca od 1 lipca 1984 r. (chociaż z licznymi zmianami), nie jest aktem prawnym dostosowanym [podkr. P. S.] do współczesnych form działalności prasy wynikających z postępu technologicznego, jaki dokonał się w okresie wielu lat od wejścia w życie prawa prasowego". Cyt. za: LEX nr 1095633. 
Wydaje się ponadto, iż zarysowane na wstępie zagadnienie zasługuje na pogłębioną i wieloaspektową refleksję, a także inspiruje do postawienia szeregu pytań dotyczących np. tego, czy na podstawie dostępnej wiedzy i dostępnych metod badawczych możliwa jest operacjonalizacja problemu NP, czy istnieje zjawisko NP, a jeśli tak, to - na czym ono polega i co jest jego źródłem? Można by zadać m.in. następujące pytania o istotę i źródła NP: (1) czy to nienadążanie prawa jest po prostu wynikiem kryzysu pozytywistycznej koncepcji prawa, a ściślej nieadekwatności pomiędzy dominującą wciąż pozytywistyczną wizją prawa a - jak zauważa Lech Morawski ${ }^{9}$ - postępującymi procesami funkcjonalnej i kulturowej dyferencjacji systemów społecznych, którym towarzyszy dyferencjacja systemów wartości?; (2) czy to nienadążanie jest skutkiem niedającego się usunąć napięcia pomiędzy, z jednej strony, dynamiczną naturą społeczeństwa funkcjonującego we współczesnym świecie (używając metafory Zygmunta Baumana) „płynnej nowoczesności”"10 a - z drugiej strony - wciąż „obowiązującą”, postulowaną ideą prawa (np. przez L. L. Fullera) względnie niezmiennego ${ }^{11}$, stabilnego (która to wizja w coraz większym stopniu oddala się od rzeczywistości w kontekście m.in. zjawiska masowej jurydyzacji)?; (3) czy wreszcie to nienadążanie prawa oznacza - odwołując się do wizji systemowej społeczeństwa ${ }^{12}$ - ryzyko nagromadzenia sprzeczności pomiędzy obowiązującą regulacją prawną a regulacją pożądaną przez społeczeństwo, co może prowadzić do jakiejś formy dezintegracji systemu społecznego, albo też do jakichś trudnych do przewidzenia zmian jakościowych tego systemu?; (4) a może - odwołując się do koncepcji „dynamicznego pola społecznego"13 - NP oznacza po prostu, że normatywny (prawny) wymiar pola społecznego (przenikający społeczeństwo na różnych poziomach: makro, mezo i mikro) nie będzie zapewniać realizacji określonych ludzkich potrzeb, wartości i celów?

Powyższe pytania (i ewentualne odpowiedzi na nie ${ }^{14}$ ) dotyczą niektórych istotnych cech współczesnej nam kultury prawnej świata zachodniego, której integralność - jak się wskazuje - z powodu masowej jurydyzacji i coraz niższej efektywności mocy sterującej prawa jest dziś trudna do osiągnięcia ${ }^{15}$. Sprzeczna

9 L. Morawski, Główne problemy współczesnej filozofii prawa. Prawo w toku przemian, Warszawa 1999, s. 26-31.

${ }^{10}$ Gdyż nie potrafi on długo trwać nieruchomo i zachowywać jednego kształtu (Z. Bauman, 44 listy ze świata plynnej nowoczesności, Kraków 2011, s. 5).

${ }^{11}$ L. L. Fuller pośród zasad składających się na wewnętrzną moralność prawa wymienia „trwałość prawa w czasie” (Moralność prawa, Warszawa 1978, s. 123-125).

${ }^{12}$ P. Sztompka, Socjologia zmian..., s. 20-24.

${ }^{13}$ Ibidem, s. 24-27.

${ }^{14}$ Udzielenie odpowiedzi na większość z powyższych pytań przekracza ramy tego opracowania.

${ }^{15}$ M. Zirk-Sadowski, Postmodernistyczna jurysprudencja?, [w:] M. Błachut (red.), Z zagadnień teorii i filozofii prawa. Ponowoczesność, Wrocław 2007, s. 23. 
z „oficjalną" ideą prawa względnie stabilnego współczesna praktyka masowego tworzenia „nowego” prawa, które ma reagować na „nowe” problemy społeczne, przyczynia się raczej do powstawania kolejnych problemów, a także faktycznie i nieodwołalnie ogranicza wolność jednostek.

3. Punktem wyjścia dla rozważań zawartych $w$ niniejszym opracowaniu jest więc do pewnego stopnia intuicyjna konstatacja problemu $\mathrm{NP}^{16}$. Jest to problem zauważany od dawna ${ }^{17}$. Odwołując się do najprostszego przykładu: rozwój nowych technologii informacyjnych, w tym Internetu, powoduje, że aktualnie obowiązujące $\mathrm{w}$ większości państw liberalno-demokratycznych regulacje dotyczące zasad i mechanizmów ochrony rozmaitych dóbr związanych z jednostką ludzką (czci, prywatności i autonomii informacyjnej jednostki itd.), np. kładące nacisk na ochronę sądową i wprost zakazujące cenzury prewencyjnej, ulegają coraz szybszej dezaktualizacji ${ }^{18}$. Biorąc pod uwagę, że organizacja państwowa powinna gwarantować ochronę praw jednostki, przy czym państwo nie może swobodnie kształtować (ani instrumentalnie traktować) ochrony dóbr osobistych, majątkowych i innych należących do sfery praw człowieka, należy stwierdzić, iż współczesny prawodawca jest zdeterminowany, z jednej strony, standardami ochrony praw jednostek, a z drugiej - działa w warunkach permanentnych i coraz szybszych zmian. Zjawisko określane $\mathrm{w}$ niniejszej pracy jako nienadążanie prawa za rozwojem społecznym jest jednym z zapewne wielu czynników mających wpływ na ograniczenie gwarancyjnej roli prawa i jego instytucji w sferze praw jednostki, przy założeniu, że prawo i jego instytucjonalne otoczenie powinny pełnić rolę gwarancyjną ${ }^{19}$.

Prawo musi być więc modyfikowane w sposób umożliwiający jego reakcję na zmiany społeczne, a z drugiej strony - jak wyżej wskazano - jedną z pożądanych cech dobrego prawa jest jego (względna) stabilność. Zbyt częste zmiany prawa stanowią nie tylko zagrożenie dla spójności porządku prawnego, lecz mogą też pozbawiać adresatów prawa poczucia bezpieczeństwa. I tak, przedmiotem regulacji prawnej powinny się stać rozpoznane (lecz być może nie wszystkie)

${ }^{16}$ Natomiast w wielu sferach prawo będzie inicjować zmiany w społeczeństwie - por. np. uwagi A. Pieniążka dotyczące wpływu prawa na budowę nowego ładu społecznego w Polsce po 1989 r., a także na temat zmian w prawie spowodowanych bezpośrednio czynnikami społecznymi (A. Pieniążek, Wpływ czynników społecznych na zmiany prawa $w$ Polsce lat dziewięćdziesiatych, [w:] L. Antonowicz, H. Groszyk, M. Sawczuk, W. Skrzydło, T. Bojarski (red.), Polska lat dziewięćdziesiatych. Przemiany państwa i prawa, t. 2, Lublin 1998, s. 465 i n.).

${ }^{17}$ Por. np. A. Michalska, Koncepcja praw człowieka a postęp naukowy i techniczny, „Państwo i Prawo" 1976, z. 6, s. 6 i n.

${ }^{18} \mathrm{~Np}$. dotyczy to prawnej ochrony przed wypowiedziami zniesławiającymi i naruszającymi prywatność, rozpowszechnianymi w Internecie, który zapewnia (w zasadzie) anonimowość wypowiadającemu się, przez co również zapewnia (faktyczną) wolność od odpowiedzialności prawnej za słowo.

${ }^{19}$ P. Sut, Kryzys gwarancyjnej roli prawa a prawoznawstwo, [w:] P. Jabłoński (red.), Czy koniec teorii prawa? Z zagadnień teorii i filozofii prawa, Wrocław 2011, s. 212-213. 
zagrożenia wolności i praw jednostek, będące następstwem np. postępu technologicznego, rozwoju biotechnologii i inżynierii genetycznej, czy też funkcjonowania tzw. nowych mediów. To podejście będzie jednak skutkować wzrostem ogólnej liczby regulacji prawnych - zaś wzrost ten będzie prowadzić do ograniczenia sfery wolności jednostki ${ }^{20}$. Oznacza to, że dystans między potrzebami społecznymi dotyczącymi realizacji określonych wartości i celów a prawem może się jeszcze zwiększać. Paradoksalnie więc, konieczność prawnej realizacji standardów w dziedzinie praw człowieka będzie wyrażać się wzrostem liczby regulacji prawnych i w efekcie ograniczeniem ludzkiej wolności.

Tak czy inaczej przyjmuję, że o nienadążaniu prawa za rozwojem społecznym (lub szerzej - zmianami społecznymi) można mówić w tych wypadkach, w których dynamika tych zmian stwarza jakieś nowe problemy (potrzeby, wartości, cele), które nie są w taki czy inny sposób objęte regulacjami prawnymi, choć powinny być nimi objęte. Powstaje tu więc zasadnicza kwestia: czy dany „nowy” problem wygenerowany przez rozwój społeczny nadaje się do prawnego uregulowania i czy powinien podlegać regulacji prawnej? Odpowiedź na to pytanie zależy oczywiście od szeregu czynników ${ }^{21}$. Pomijając kwestię zobowiązań międzynarodowych i konstytucyjnych państwa w sferze praw jednostki, poza moimi rozważaniami pozostawiam zasadniczy problem polityki prawa: zasadności ewentualnej „nowej” regulacji prawnej społecznych potrzeb, wartości i celów, które ,aktualnie” nie są realizowane przez prawo.

4. W istocie prawo jest instrumentem dążenia przez ludzi do osiągania celów. Pozostawiając na boku kwestię odwiecznego poszukiwania jakiegoś idealnego celu prawa ${ }^{22}$, należy przyjąć, że prawotwórstwo jest działalnością celową w najprostszym, technicznym znaczeniu tego słowa, gdyż realizuje (z różnym skutkiem), i zapewne powinno realizować, określone zadania na różnych (makro, mezo i mikro) poziomach społecznych. Działalność ta ma sens tak długo, jak długo prawo może zapewnić skuteczną realizację tych, rozumianych zresztą bardzo szeroko, społecznych celów. W związku z tym, zdając sobie sprawę ze znanych kontrowersji dotyczących instrumentalnego pojmowania prawa ${ }^{23}$, przyjmuję, że prawo jest instrumentem realizacji określonych społecznych potrzeb, wartości i celów. Jeżeli zaś potraktujemy prawo jako instrument ich realizacji, to istotne

${ }^{20}$ Por. szerzej: J. Guść, System prawa w warunkach nadmiaru prawa, [w:] O. Bogucki, S. Czepita (red.), System prawny a porzqdek prawny, Szczecin 2008.

${ }^{21}$ Por. np. rozważania J. Wróblewskiego dotyczące ustalania potencjalnych środków prawnych realizacji celu (J. Wróblewski, Teoria racjonalnego tworzenia prawa, Wrocław-WarszawaKraków-Gdańsk-Łódź 1985, s. 148-151).

${ }^{22}$ Szerzej na temat zagadnienia definiowania prawa poprzez odwołanie się do specyficznych celów prawa - por. np. D. von der Pfordten, Czym jest prawo? Cele i środki, „Archiwum Filozofii Prawa i Filozofii Społecznej" 2010, nr 1 (1), s. 10 i n.

${ }^{23} \mathrm{Na}$ temat kontrowersji dotyczących instrumentalnego pojmowania prawa, w tym krytyki takiego ujęcia - por. W. Gromski, Autonomia i instrumentalny charakter prawa, Wrocław 2000, s. 83-122. 
staje się zagadnienie stopnia efektywności tej realizacji (realizowalności). Rzeczywistym problemem społecznym i jednostkowym może być nie tylko instrumentalne traktowanie prawa przez rządzących, lecz także brak realizacji określonych społecznych potrzeb, wartości i celów, co może wynikać z wielu przyczyn, a jedną $\mathrm{z}$ nich będzie nienadążanie prawa.

Przyjąć należy, że nienadążanie prawa nie jest jednorodne. Maciej Wojciechowski wskazuje na (używając terminologii tego autora) następujące kategorie nieaktualności normy prawnej (zastrzegając, iż podział ten nie ma charakteru rozłącznego i prawdopodobnie zupełnego): (1) instrumentalna - gdy norma prawna przestała być „dobrym” instrumentem realizacji celu, który nie uległ zmianie; (2) aksjologiczną - gdy cel, dla którego norma została ustanowiona, został zrealizowany lub przestał być uznawany za wartościowy; (3) językową - gdy w tekście prawnym występują zwroty archaiczne pod względem rzeczowym lub słowniko$\mathrm{wym}^{24}$. Nie przesądzając o tym, czy zaproponowany powyżej podział jest trafny, należy wskazać, że najbliższa rozważaniom zawartym w niniejszej pracy jest zgodnie z terminologią cytowanego wyżej autora - nieaktualność (ad. 1) instrumentalna normy prawnej, przy czym z problemem NP mamy do czynienia nie tylko wówczas, gdy norma przestała być - choć wcześniej była - instrumentem efektywnej realizacji jakiegoś celu, ale także, gdy pojawiają się nowe potrzeby, wartości, cele i aktualnie brakuje regulacji prawnej pozwalającej zabezpieczyć ich realizację.

Tak czy inaczej, wykorzystując na zasadzie analogii odróżnienie pozornych i realnych luk w prawie, można stwierdzić, iż nienadążanie prawa (w tym nieaktualność instrumentalna normy prawnej) może mieć postać pozorną (tzn. wymagającą poszukiwania rozwiązań $\mathrm{w}$ ramach obowiązującego systemu prawnego przy użyciu dyrektyw i metod wykładni, wnioskowań prawniczych itp., a więc niedającą podstaw do stwierdzenia NP) albo realną (gdy jedynym możliwym rozwiązaniem będzie interwencja prawodawcy), a także różne konsekwencje, z reguły negatywne oceniane. Realne nienadążanie prawa może mieć konsekwencje daleko idące, prowadzące np. do naruszenia przez państwo standardów w dziedzinie praw człowieka, a w sferze życia społecznego - np. prowadzące do braku zapewnienia realizacji określonych wartości. $Z$ taką sytuacją mamy do czynienia, gdy z jakichś źródeł prawnych lub pozaprawnych (np. z aksjologii danego systemu społecznego) wynika nakaz prawnej realizacji (ochrony) określonej wartości-ce$\mathrm{lu}^{25}$ (np. ochrony prywatności, ochrony dobrego imienia itd.), przy jednoczesnym: (I) stwierdzeniu przez organy (np. stosujące prawo), że doszło do naruszenia lub

${ }^{24}$ M. Wojciechowski, Historyczne i metodologiczne aspekty rozważań o postęie prawa, [w:] S. Wronkowska (red.), Polska kultura prawna a proces integracji europejskiej, Zakamycze 2005, s. 258-260.

${ }^{25}$ Por. K. Pałecki, Neutralizacja aksjologiczna w prawie - zarys koncepcji (Neutralization of Values in Law - Main Concepts), tekst udostępniony mi w formie elektronicznej (wersja nadesłana: 5.09.2012), s. 6-7. 
braku realizacji tej wartości-celu, i co więcej - (II) braku aktualnie obowiązującej regulacji prawnej pozwalającej zabezpieczyć realizację tej wartości, lub też istniejąca regulacja z takich czy innych względów (np. nienadążania prawa) nie chroni (nie zabezpiecza) tejże wartości (o czym szerzej w pkt 6).

5. Niezależnie od powyższego, sądy - w zależności od okoliczności - stosują różne, narzucone przez kulturę prawną, metody „radzenia sobie” z problemem nienadążania prawa. Stwierdzenia zawarte w uzasadnieniach niektórych orzeczeń wskazują, iż sądy w taki czy inny sposób uwzględniają problem NP. I tak, przykładowo, stwierdzenia Sądu Najwyższego zawarte w uzasadnieniu postanowienia z dnia 23 września 2009 r., I KZP 10/0926, wskazują, iż zdaniem tego sądu zwroty szacunkowe ${ }^{27}$ (w tym wypadku chodziło o zwrot ,znaczna ilość") mogą być środkami służącymi do dostosowywania prawa do problemów generowanych przez rozwój społeczny. Natomiast postanowieniem z dnia 29 września 2004 r., I KZP 22/04²8, Sąd Najwyższy, odwołując się do woli aktualnego ustawodawcy (wykładni obiektywnej), rozstrzygnął wątpliwość dotyczącą tego, czy wyłudzenie sygnału telewizyjnego należy kwalifikować jako wykroczenie szalbierstwa (tak uznał), czy też ,mamy do czynienia z luką prawną związaną z niedostosowaniem przepisów do szybko postępującego rozwoju technologicznego". Z kolei w uzasadnieniu wyroku z dnia 26 września 2008 r., II OSK 1101/0729, Naczelny Sąd Administracyjny w Warszawie stwierdził: ,[...] uregulowanie zawarte $\mathrm{w}$ art. 57 § 5 k.p.a. wyraźnie nie nadąża za zmianami społecznymi [podkr. P. S.] [...]. Z tego względu wykladnia rozszerzająca [podkr. P. S.] możliwość skutecznej ochrony praw w postępowaniu administracyjnym i następnie przed sądem jest uzasadniona". W ostatnim z cytowanych zdań sąd wskazuje na wartości (prawa strony) chronione wyżej wymienionym przepisem k.p.a. ${ }^{30}$

${ }^{26}$ OSNKW 2009/10/84. Przedmiotem postanowienia SN było zagadnienie prawne wymagające zasadniczej wykładni przepisów ustawy z dnia 29 lipca 2005 r. o przeciwdziałaniu narkomanii (Dz. U. 2005, nr 179, poz. 1485 ze zm.) dotyczące zakresu znaczeniowego pojęcia „,znaczna ilość", użytego w przepisach tej ustawy. W uzasadnieniu tego postanowienia SN dochodzi m.in. do wniosku, że: ,[...] żaden wzorzec stworzony przez Sąd Najwyższy nie jest w stanie objąć tych wszystkich przypadków, które mogą w przyszłości zaistnieć przy obecnym postępie technologicznym i wytworzenia nowych, jeszcze groźniejszych dla życia i zdrowia człowieka [wartości chronione przepisami tej ustawy - dop. P. S.] narkotyków syntetycznych, zdatnych wywołać zamierzony skutek przy coraz mniejszych wagowo ilościach [...]”.

${ }^{27} \mathrm{Na}$ temat zwrotów szacunkowych - por. w szczególności: M. Zieliński, Wykładnia prawa. Zasady, reguły, wskazówki, Warszawa 2002, s. 172-174.

${ }^{28}$ OSNwSK 2004/1/1691.

${ }^{29}$ ONSAiWSA 2009/3/54.

${ }^{30}$ NSA przyjął bowiem, że: „Jeśli pismo zostało nadane w zagranicznym urzędzie pocztowym, termin jego wniesienia należy uznać za zachowany, jeżeli przed jego upływem pismo to zostało przekazane polskiej placówce pocztowej operatora publicznego (art. 57 § 5 pkt 2 k.p.a.)”. Cyt. za: LEX nr 500037. 
Zakładając, że przedstawione powyżej przykładowe rozstrzygnięcia - stanowiące egzemplifikację tezy, że NP może mieć postać pozorną - są trafne, należy stwierdzić, że sądy, dostrzegając problem nienadążania prawa, stosują przyjęte w naszej kulturze prawnej dyrektywy i metody postępowania interpretacyjnego (takie jak np. wykładnia obiektywna zgodna z wolą aktualnego prawodawcy, wykładnia rozszerzająca, stosowanie klauzul generalnych) w celu dostosowania regulacji prawnych do zmieniających się warunków społecznych.

Istotne, z uwagi na określone skutki w sferze społecznej i jednostkowej, są jednak te przypadki, w których brak jest możliwości zastosowania reguł i metod postępowania interpretacyjnego w celu dostosowania obowiązującej regulacji prawnej do nowo powstałego problemu ${ }^{31}$. Ów brak możliwości może wynikać z obowiązujących w naszej kulturze prawnej zakazów (np. stosowania wykładni rozszerzającej i analogii legis w niektórych gałęziach systemu prawa). Tego typu przypadki prowadzą do „realnego” nienadążania prawa, w sytuacji, gdy dana regulacja prawna przestała być, choć wcześniej była, instrumentem efektywnej realizacji wartości-celu, ale także, gdy pojawiają się nowe wartości-cele, i aktualnie nie ma regulacji prawnej pozwalającej zabezpieczyć ich realizację.

$\mathrm{Na}$ podstawie zapadłych w konkretnych sprawach rozstrzygnięć możliwa jest ocena, czy dana regulacja skutecznie realizuje (chroni) określoną wartość-cel. Warunkiem koniecznym miarodajności tej oceny jest jednak zastosowanie przez organ stosujący prawo prawidłowych reguł postępowania interpretacyjnego $\mathrm{w}$ odniesieniu do stosowanej $\mathrm{w}$ danej sprawie regulacji, właściwe zastosowanie reguł procedury, a w końcu prawidłowe ustalenie stanu faktycznego tej sprawy. Przy tym zapadłe rozstrzygnięcie organu stosującego prawo, które przyznaje ochronę określonej wartości (zapewniające realizację tej wartości), stwarza jedynie faktyczne domniemanie „nadążania” prawa za rozwojem społecznym, gdyż przy nieco odmiennym stanie faktycznym nie jest wykluczone rozstrzygnięcie odmawiające ochrony (np. zniesławienie w „realnym” życiu

${ }^{31}$ Przykładowo, wyrokiem z dnia 14 grudnia 2010 r. (V SA/Wa 1467/10) WSA w Warszawie rozstrzygał kwestię prawidłowości taryfikacji celnej sprowadzonego przez stronę skarżącą towaru (alkomatów). Sąd, mimo że przyjął, iż: „[...] Zdaniem Sądu postęp techniczny powoduje, że prawodawstwo $\mathrm{w}$ zakresie klasyfikacji taryfowej nie nadąża za rozwojem nowych technologii [podkr. P. S.], przez co to, co przed laty można było określać mianem skomplikowanej aparatury, aktualnie stanowi przyrząd [...]" (cyt. za: LEX nr 819085), to jednak przeszedł nad tym problemem nienadążania prawa do porządku dziennego. WSA za słuszne uznał bowiem stanowisko organów celnych, że podpozycja 902710 (aparatura do analizy gazu lub dymu) dokładniej od podpozycji 902780 (pozostałe przyrządy i aparatura) identyfikuje przedmiotowe alkomaty, gdyż badanie przedmiotowymi alkomatami polega na oznaczaniu zawartości alkoholu we krwi za pomocą analizy powietrza (mieszaniny gazów) wydychanego przez osobę badaną, przyjmując za kluczowy opis spełnianej funkcji przez alkomaty (analizę gazu) - por. LEX nr 819085. Rozstrzygnięcie WSA niekorzystne dla strony, wydane na podstawie prawa - jak sam zauważył ten sąd - niedostosowanego do rozwoju nowych technologii, niewątpliwie podważa wartość, jaką jest zaufanie obywatela do państwa i prawa. 
- przyznana ochrona; zniesławienie w Internecie - z uwagi na anonimowość naruszyciela - odmowa ochrony). Z kolei odmowa organu przyznania ochrony konkretnej wartości (odmowa realizacji wartości) stwarza faktyczne domniemanie nienadążania prawa tylko wtedy, gdy owo nienadążanie jest przynajmniej jedną z przyczyn tego negatywnego rozstrzygnięcia - wskazaną wprost przez organ lub dającą się zrekonstruować na podstawie analizy stanu faktycznego i stanu normatywnego sprawy.

6. Dotychczasowe rozważania prowadzą do wniosku, że społecznym problemem może być brak realizacji szeregu wartości-celów, stanowiących podstawę aksjologiczną prawa (lub poszczególnych regulacji prawnych) z uwagi na, ogólnie ujmując, nienadążanie tego prawa za rozwojem społecznym. Chodzi tu o sytuacje, gdy regulacje prawne nie są (choć być może wcześniej były) efektywnym instrumentem realizacji rozmaitych wartości-celów (będących aksjologicznymi przyczynami ustanowienia tych regulacji). W związku z tym szczególnie interesujące wydają się te przypadki, gdy spełnione są - zgodnie z ustaleniem Krzysztofa Pałeckiego - warunki realności podstawy aksjologicznej danego aktu prawotwórczego ${ }^{32}$, przy jednoczesnym: (I) stwierdzeniu przez organy (np. stosujące prawo), że doszło do naruszenia lub braku realizacji wartości-celu (wartości-celów) „zawartej” (,zawartych”) w tymże akcie prawotwórczym, i co więcej, (II) odmowie - z uwagi np. na specyficzny kontekst sytuacyjny - przyznania przez te organy ochrony tej wartości (tym wartościom). Przypadek tego typu - stanowiący egzemplifikację tezy o realnym NP - zostanie przedstawiony poniżej.

Problem nienadążania prawa za rozwojem społecznym w sferze funkcjonowania mediów (w tym Internetu) dotyczy np. ochrony dóbr osobistych (naruszanych np. na forach internetowych). Anonimowość wypowiedzi naruszających dobra osobiste w sieci powoduje, że niezwykle trudna staje się sądowa ochrona tych dóbr. Problem ten jest istotny, z uwagi na fakt, iż państwo, jako gwarant ochrony praw człowieka, powinno z jednej strony chronić wolność wypowiedzi (także w sieci) i nie może posłużyć się cenzurą prewencyjną (np. art. 54 Konstytucji $\mathrm{RP}$ ), a z drugiej - nie powinno tolerować wypowiedzi naruszających ludzką godność, stanowiących przestępstwo lub nawołujących do popełnienia przestępstwa.

W tym kontekście watpliwości na gruncie obowiązującego prawa polskiego budzi kwestia odpowiedzialności za tzw. posty (najczęściej krótkie wiadomości wysłane na internetowe fora dyskusyjne). Tradycyjna prasa „drukowana” zamieszcza listy do redakcji, które są traktowane tak, jak każdy inny materiał prasowy

${ }^{32}$ Zdaniem K. Pałeckiego, warunki realności podstawy aksjologicznej aktu prawotwórczego są następujące: (1) jednoznaczne przypisanie podstawy aksjologicznej do danego aktu przez jego adresatów, a także (2) niezerowy stopień pragmatyczności (realizowalności) wartości-celu według przekonań adresatów danego aktu, oraz (3) niezerowy stopień kognitywnej racjonalności wymogów danej regulacji prawnej, tj. gwarantujący zadawalający dla adresatów poziom realizacji wartości, a wreszcie (4) uzgadnialność wartości-celów zawartych w regulacji z preferencjami jej adresatów. Por. K. Pałecki, op. cit., s. 26-27. 
przygotowany przez redakcję, a co za tym idzie, za treść listu do redakcji, który narusza czyjeś prawa, odpowiada prasa, tak jak za felieton stworzony przez zatrudnionego w redakcji dziennikarza ${ }^{33}$. Jest to uzasadnione, gdyż list do redakcji jest przez tę redakcję (redaktora) dopuszczony do publikacji i ona może przeanalizować treść tego listu pod kątem ewentualnego zagrożenia lub naruszenia czyichś dóbr osobistych. Natomiast przyjmuje się, że posty nie są listami do redakcji, a administrator portalu internetowego, na którym umieszczony został taki post (np. naruszający czyjeś dobra osobiste), może uchylić się od odpowiedzialności za jego treśćc ${ }^{4}$.

Wracając do analizy przypadków dotyczących realnego NP, warto zwrócić uwagę na postanowienie Sądu Najwyższego z dnia 7 maja 2008 r., III KK 234/07, rozstrzygające sprawę znieważenia oraz zniesławienia pewnego nauczyciela akademickiego na forum internetowym (poprzez nazwanie go „erotomanem”) ${ }^{35}$. Otóż stwierdzenie przez Sąd Najwyższy, że tekst, którego treścią poczuł się dotknięty oskarżyciel prywatny, miał charakter zniesławienia, nie doprowadziło do pociągnięcia oskarżonej, będącej właścicielką komputera, z którego ten tekst został nadany, do odpowiedzialności karnej. Jak bowiem przyjął Sąd Najwyższy w tym orzeczeniu:

Nie sposób w aktualnym stanie prawnym uznać, że samo udostępnienie komputera powoduje odpowiedzialność karną jego właściciela, w razie gdyby okazało się, że korzystający z niego dopuścili się przestępstwa. W aktualnym stanie rzeczy nie sposób przyjąć, aby oskarżona B. W. mogła ponosić odpowiedzialność karną za zniesławienie lub zniewagę tylko z tej racji, że z posiadanego przez nią komputera skorzystała jakaś osoba, zamieszczając na portalu internetowym zniesławiającą wiadomość [...].

${ }^{33}$ Tak np. SN w wyroku z dnia 28 września 2000 r., V KKN 171/98, OSNKW 2001/3-4/31.

${ }^{34}$ Por. np. S. Wikariak, Prowadzacy serwis $W W W$ nie odpowiada za cudzy wpis - notatka opublikowana na stronie www.rp.pl 16 grudnia 2008 r., zawierająca informację o orzeczeniu SR w Słupsku, który uznał, iż komentarze (nawołujące do popełnienia przestępstwa) zamieszczone na portalu przez jego użytkowników nie są materiałem prasowym. Zdaniem tego sądu odpowiedzialność osoby udostępniającej swój serwer innym - za przechowywane na nim dane-może być wyłączona na podstawie art. 14 ustawy o świadczeniu usług drogą elektroniczną (Dz. U. 2002, nr 144, poz. 1204 ze zm.). Oczywiście wyłączenie odpowiedzialności podmiotu prowadzącego portal internetowy na podstawie tego przepisu nie rozwiązuje problemu naruszania dóbr osobistych w sieci.

${ }^{35} \mathrm{~W}$ odniesieniu do przysługujących jednostce (w tym przypadku - nauczycielowi akademickiemu, który był w sprawie oskarżycielem prywatnym) dóbr (wartości-celów) chronionych przepisami prawa karnego Sąd Najwyższy stwierdził w tym orzeczeniu m.in.: ,[...] Przestępstwo zniewagi polega na użyciu słów obelżywych lub sformułowaniu zarzutów obelżywych lub ośmieszających, postawionych w formie niezracjonalizowanej. [...] Analiza treści wspomnianego wpisu zdaje się dowodzić, iż nie będąc zniewagą, miał on jednak charakter zniesławiający. Użycie terminu «erotoman» stanowiło pomówienie wykładowcy o takie postępowanie i właściwości, które z jednej strony mogą go poniżyć w opinii publicznej, zarówno w opinii studentów, jak i w opinii innych wykładowców, a z drugiej - narazić na utratę zaufania potrzebnego do wykonywania zawodu nauczyciela akademickiego” („Biuletyn Prawa Karnego” 2008, nr 10, s. 33). 
Przywołane orzeczenie, które oczywiście rozstrzyga konkretną i indywidualną sprawę, lecz dotyka szerszego, społecznego problemu naruszania szeregu wartości-celów w sieci, wydaje się prowadzić do następujących wniosków:

- niewątpliwie $\mathrm{w}$ aktualnie obowiązującym porządku prawnym w Polsce wartościami-celami chronionymi przepisami prawa karnego (art. 212 k.k. - przestępstwo zniesławiania; art. 216 k.k. - przestępstwo zniewagi) są cześć i godność osobista człowieka;

- Sąd Najwyższy w cytowanym wyżej orzeczeniu stwierdził, że przedmiotowe wpisy na forum internetowym miały charakter zniesławiający, a więc stwierdzono naruszenie określonej wartości chronionej przez prawo;

- jednocześnie Sąd Najwyższy stwierdził, że w okolicznościach tej sprawy nie można przypisać odpowiedzialności karnej oskarżonej na tej podstawie, że z posiadanego przez nią komputera wysłany został zniesławiający wpis umieszczony na przedmiotowym forum.

Prowadzić to może do wniosku, że m.in. wobec rozwoju nowych technologii informacyjnych przedmiotowa regulacja prawna jest dysfunkcjonalnym instrumentem realizacji (ochrony) pewnych wartości-celów naruszanych w sieci internetowej, takich jak np. cześć i godność osobista człowieka.

Wydaje się, że w wyżej opisanym przypadku dotyczącym odpowiedzialności karnej za wpis na forum internetowym spełnione były warunki realności podstawy aksjologicznej danego aktu prawotwórczego, przy jednoczesnym stwierdzeniu przez organy stosujące prawo, że doszło do naruszenia (braku realizacji) określonych wartości-celów „zawartych” w prawie oraz stwierdzeniu przez te organy, że na podstawie analizowanej regulacji prawnej nie jest możliwa ochrona (zabezpieczenie) tychże wartości.

Stwierdzić więc należy w analizowanym przypadku brak realizacji wartości-celów opisanych powyżej, stanowiących podstawę aksjologiczną prawa, z uwagi na - przede wszystkim - nienadążanie tego prawa za rozwojem społecznym.

Można więc przyjąć, że efektem nienadążania prawa za rozwojem społecznym (społecznymi zmianami) jest brak realizacji wartości-celów przez system prawny, w sytuacji, gdy wartości te z takich czy innych przyczyn „domagają" się prawnej regulacji. Rzeczą zasadniczą jest więc prawidłowe wskazanie tych społecznych potrzeb, wartości i celów, które powinny podlegać prawnej realizacji na danym etapie rozwoju społecznego. 